\title{
HYDROENERGETIC USE OF HYDRAULIC STRUCTURES ON THE OŁAWA RIVER
}

\author{
Robert Kasperek, Robert Głowski \\ Institute of Environmental Engineering, Faculty of Environmental Engineering and Geodesy, Wrocław University of Environmental \\ and Life Sciences, Pl. Grunwaldzki 24, 50-363 Wrocław
}

\begin{abstract}
Aim of the study

The aim of the paper is prepare a report on hydraulic structures on the Oława River in terms of constructing hydropower plants and assessing rivers hydropower potential.
\end{abstract}

\begin{abstract}
Material and methods
There are no small hydropower plants (SHP) on the Oława River. The authors carried out measurements and calculations of flows and water levels for the period of 2005-2015, classified the humidity conditions, as well as based the hydropower calculations, reports on water constructions and the river's potential calculations on the adopted average year. The average year was determined using the RPI indicator. The authors inspected existing structures in the field for the construction of SHP and assessed their technical condition and the possibilities of increasing their slopes. The spillway capacity, potential power of the proposed SHP locations and annual energy production were estimated based on the Hoffmann method. The power was determined from the formula $\mathrm{P}=8.2 \mathrm{QH}$, where the capacity Q was assumed at $0.9 \mathrm{SSQ}$, the slope $\mathrm{H}$ was taken based on the structure tests, and energy production was determined from the formula $\mathrm{E}=\mathrm{TP}$, where the time of power use $\mathrm{T}=6000 \mathrm{~h} /$ year.
\end{abstract}

\section{Results and conclusions}

Fourteen structures located on the Oława River were examined. Its hydropower potential was estimated at $3.24 \mathrm{GWh}$. It is able to provide clean electricity for 1240 farms. Such use of Oława's potential would contribute to reducing emissions, stabilizing hydrological conditions on the river and guaranteeing better living conditions for populace.

Keywords: river, weir, hydropower plant, Archimedes' screw, energy production

\section{INTRODUCTION}

Hydropower is one of the cleanest and environmentally friendly sources of electricity. Utilizing the water potential has a long tradition in Poland, as solutions for driving mills, sawmills, fulling, forges and other economic and industrial works have long been known. In view of the growing demand for energy, it is nec- essary to search for the best possible use of existing water constructions in terms of clean, green energy production. Good technical conditions of these buildings and properly conducted operations are key elements here (Depczyński and Szamowski, 1999; Rozporządzenie, 2007; Michalec et al., 2017). Meeting these criteria significantly contributes to an increase in the use of water energy, and brings Poland closer to

凶e-mail: robert.kasperek@upwr.edu.pl 
meeting its obligations in the light of EU renewable energy directives up to 2020, as well as new perspectives for the period 2021-2030 (Dyrektywa PE, 2018; Ustawa, 2019). Poland has favourable conditions for developing hydropower, especially small hydropower plants (Operacz and Grahl-Madsen, 2018; Wiatkowski and Rosik-Dulewska, 2012). Unfortunately, the pace of building new power plants is still too low. Currently, it is estimated that Poland's technical hydropower resources are used in a dozen or so percent, and the European average is approx. 45\% (Dolata, 2012; Miazga, 2013). European Union countries are aware that hydropower is an important element additionally stabilizing the energy network and ensuring energy security. In many countries, hydropower plants provide the most electricity of all renewable energy sources. At the moment, small hydropower plants in the EU generate $41,000 \mathrm{GWh}$ of electricity, reducing the $\mathrm{CO} 2$ emissions by about 29 million tons annually. In Poland, SHPs do not exceed $5 \mathrm{MW}$, while in Europe the power value is $10 \mathrm{MW}$. The scope of power is different for different EU countries due to a lack of agreement between countries regarding the definition of SHPs. In Poland, there are micro power plants with a capacity of up to $300 \mathrm{~kW}$, mini power plants with $301-1000 \mathrm{~kW}$ and small hydropower plants in the range from 1 to $5 \mathrm{MW}$. An important element of increasing the energy potential of flowing water is to improve ecological qualities, in regard to which the authors examined several dozen SHPs that have been rebuilt and modernized in the last 30 years. The analysis of the above-mentioned SHPs was carried out both in terms of structural changes and achievable hydropower potential. SHPs created in the years 1990-2020, i.e. Bieleckie Młyny on the Czarna Nida river with the first snail turbine manufactured in Poland, Gorzanów (Nysa Kłodzka river), Krzywnica (Krępiel river), Dworek (Orzyc river), 11 SHPs on the Ner river, Bobrany Dwór (Smrocek river), Cieszyn, Michałów (Nogat river), Namyślin (Myśla river), Goryń (Radomka river), Jaracz (Wełna river), Wolica (Czarna Nida river), SHP on the Radunia river, Rzeszów (Wisłok river), Nowa Wieś Rzeczna (Wierzyca river), Czersko Polskie (Brda river), Dolina Pięciu Stawów, Iłki (Bystra river), Stoki Duży (Kamienna river), Buśnia (Mątawa river), Ołownik (Węgorapa river), Gałęnia Mała (Słupia river), Trzebieszowice (Biała Lądecka river), Kopin (Oder river),
Skawina (Skawina river), Borek Szlachecki (Łączany), Piotrownice (Nidzica river), and recently a German power plant near Lake Starnberger See (Germany) (Ossberger, 2019). The analysis of the aforementioned SHPs also provided the basis for a preliminary assessment of construction costs and the payback period for this type of investment.

The purpose of the paper is a report on the Olawa river in terms of existing water structures and potential sites, where a small hydropower plant (SHP) can be located, and an estimation of its hydropower potential. Field research and analytical calculations allowed for building several power plants that provide clean energy for the local population and production plants.

\section{MATERIALS AND METHODS}

Currently, the hydropower potential of the Oława river is not utilized at all. There is no power plant along its entire length that would use existing dammings. The assumed goal and research hypotheses were pursued on the basis of measurements and calculations:

- particular water levels for water gauge stations on the Olawa River from the period of 2005-2015,

- characteristic flows,

- classification of humidity conditions from a weather station,

- report on existing hydraulic structures in the field,

- hydropower potential in already existing dammings and in proposed new locations for the construction of SHP.

Measurement data from water gauge stations allowed to register water levels and characteristic flows (Ozga-Zielińska, 1997). The Kaczorowska method (1962) determines an average (normal) year in the 2005-2015 period, which is provides a model for estimating the possible hydropower potential of the Oława River. Regardless of the type of hydropower plant, the potential depends primarily on utilizing flow and damming (Henke et al., 2010; Kasperek and Wiatkowski, 2010). This means that energy production at SHP mainly depends on its location (Gąsiorek et al., 2006; Kasperek and Wiatkowski, 2014; Wiatkowski and Kasperek, 2012). The selection of the most favourable locations for potential SHPs was guided by field tests. This allowed checking 14 dams that present a possibility of building a power plant. 
Recommendations were applied to methods for determining the particular water levels and characteristic flows, with special attention to the levels and main flows of the first and second degree (Ozga-Zielińska, 1997). Important information regarding the examined watercourse is provided in the Oława river catchment datasheet developed by IMGW as part of flood risk management plans.

A watercourse's hydropower potential depends on a slope and flow in a riverbed. Because Poland is located in a relatively lowland area, with small drops, so its hydropower potential is relatively limited, at the level of about 13.7 TWh/year (Dolata, 2010; Operacz and Grahl-Madsen, 2018). Unfortunately, even these resources are utilised only in $12 \%$. The Oława river fits to this image, as most Polish rivers, perhaps this explains why despite having damming structures on its course, none of them is used for energy purposes. The water energy resources of the studied watercourse are estimated as theoretical resources that can be obtained.

Depending on the meteorological situation, precipitation may also have extremely different values. The hydropower potential of the Olawa river was determined on the basis of Hoffman's assumptions (1991). It assumes a use of an average annual flow in a cross section of a damming structure, while an installed spillway capacity can be measure by three variants employing different times of power plant operation.

The authors propose Archimedes turbines (Steller, 2013; Pęcherz and Szlęzak, 2017) as possible technical solutions for turbines to be used in planned locations of SHP on the Olawa river. Introduction of this turbine is related to a new approach in the area of clearing watercourses along with protection and free migration of ichthyofauna upstream and downstream.

Traditional fish passes divide the hydraulic drop within a damming structure into a series of connected basins. The parameters of these basins (chambers) are selected so that specific species of fish can migrate and rest freely (Kasperek and Wiatkowski, 2010; Szkudlarek et al., 2019). A properly designed Archimedes' screw allows both simultaneous transport of water and fish up- and downsream. Technically, such a fish pass consists of an ascending track - pumping water up and a descending track discharging it down. It is called an active fish pass. Compared to a traditional fish pass, it requires less space, is much cheaper and easier for fish to overcome, because they are lifted together with water, so they do not lose energy for beating differences in water levels in basins and water current in slits or spillways/discharges (Kalina, 2019).

\section{Hydrographic and hydrological characteristics of the Otawa river}

The Oława river is one of the main tributaries of the Middle Oder (merging in the city of Wrocław at $\mathrm{km}$ 330.9). The area is located in the central part of the Middle Oder region, in the Lower Silesian Voivodeship. Oława's source lies in the Sudetes Foothills at an altitude of about $315 \mathrm{~m}$ a.s.l., the total length of its watercourse is about $91.7 \mathrm{~km}$, with a catchment area estimated at about $1160.03 \mathrm{~km}^{2}$. The average decrease of the catchment ranges within $0.62 \%$, and the density of its river network is $0.34 \mathrm{~km} \cdot \mathrm{km}^{-2}$. The catchment has a relatively well-developed hydrographic network, two main tributaries: Gnojna and Krynka. The river in the rest of the catchment only receives small watercourses that do not have a significant impact on its water resources. The Oława valley is developed, with numerous millraces and side arms. From Ziębice, the riverbed is partly artificially transformed. Below Strzelin, the river valley widens to approx. $3 \mathrm{~km}$.

There are in the Oława river catchment several dry flood control reservoirs and Oławek flow-and-retention polder. Within the polder there are aquifers of the city of Wrocław and the regions of Radwanice, Siechnice and Mokry Dwór. The catchment area of the Oława river is controlled by two water gauge stations of the Institute of Meteorology and Water Management - National Research Institute, i.e. in Oława and Zborowice (see: Table 1). The authors carried out an analysis of the energy use of the Olawa river for the period of 2005-2015. Further research and calculations of hydropower potential are planned for 2016-2020.

The river, except for the source section, flows only through built-up areas, i.e. Ziębice, Strzelin, Wiązów, Oława and Wrocław. The catchment has an agricultural character, with intensive production, especially in the middle of its course, afforestation in this area is relatively small, about $20 \%$. The Nysa-Oława transfer channel, which was built in 1971 and supplies Oława with Nysa Kłodzka waters, plays an important role in the catchment. Water transfer is necessary due to insufficient own resources of the watercourse that is 


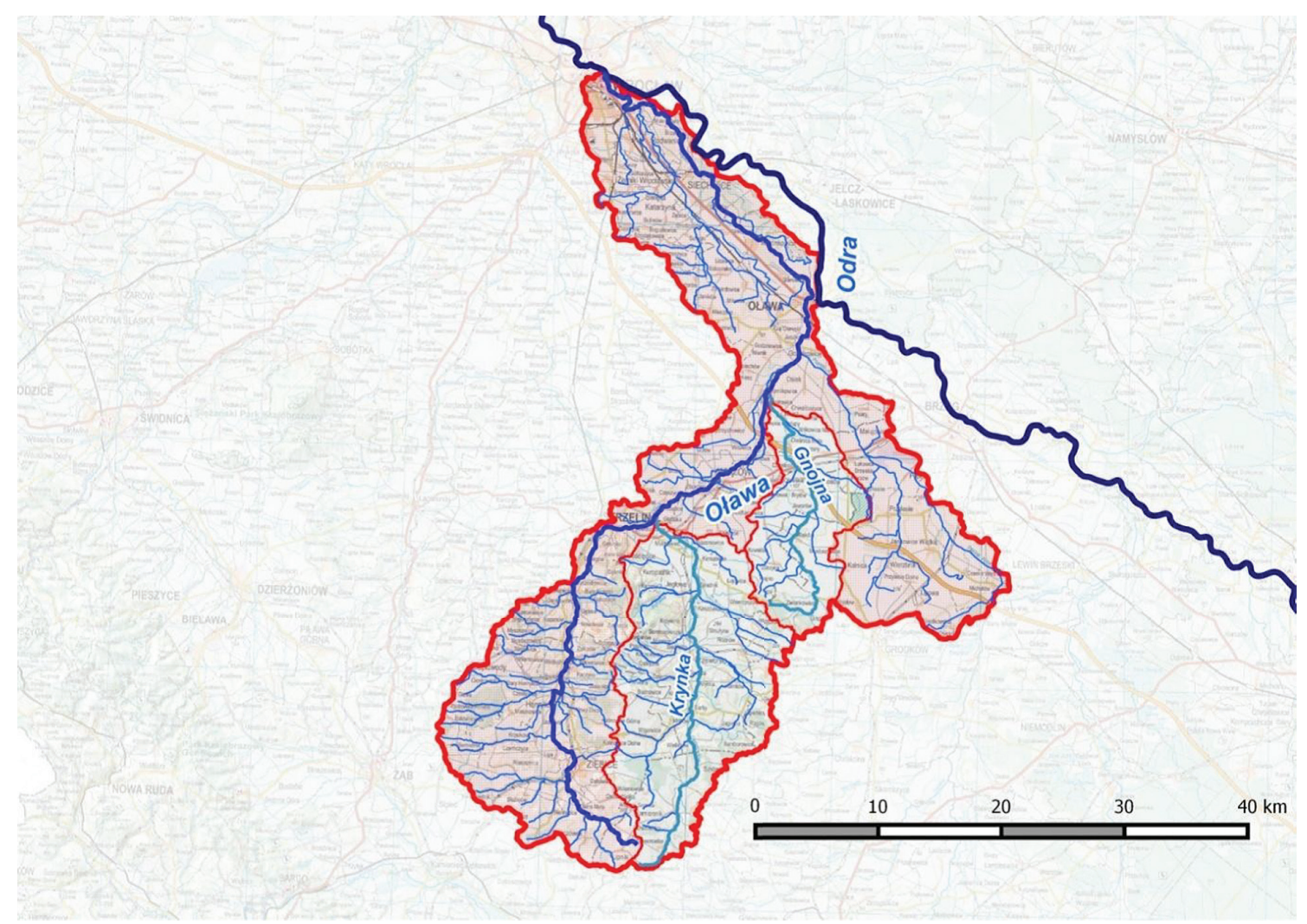

Fig. 1. Oława river catchment and tributaries

Table 1. IMGW water gauge stations on the Oława river

\begin{tabular}{cccccccc}
\hline \multirow{2}{*}{$\begin{array}{c}\text { Water } \\
\text { gauge }\end{array}$} & River & $\mathrm{Km}$ & $\begin{array}{c}\text { Catchment } \\
\text { area }\left[\mathrm{km}^{2}\right]\end{array}$ & $\begin{array}{c}\text { Period } \\
\text { research }\end{array}$ & $\begin{array}{c}\text { SNQ } \\
\text { (mean annual } \\
\text { minimum flows) }\end{array}$ & $\begin{array}{c}\text { SSQ } \\
\text { (mean annual } \\
\text { average flows) }\end{array}$ & $\begin{array}{c}\text { SWQ } \\
\text { (mean annual } \\
\text { maximum flows) }\end{array}$ \\
\hline Zborowice & Oława & 53,37 & 568.85 & $2005-2015$ & 0.31 & 2.09 & 13.12 \\
\hline Oława & Oława & 32.14 & 957.00 & & 1.47 & 4.11 & 22.37 \\
\hline
\end{tabular}

Wrocław's main source of consumption water. Due to supplying Wrocław agglomeration with water, the Oława river has special significance in the voivodeship monitoring network. Therefore, river waters should meet the quality requirements for class I.

In order to determine the mean flow from the SSQ multiannual period necessary for further analysis of hydropower parameters, the authors calculated char- acteristic flows of the first and second degree in the Oława and Zborowice cross-sections. The first order states include the highest, lowest and average values in the selected year, and then the values were again divided from the obtained set, providing the main flows of the second degree (see: Tables 2 and 3 ).

Due to the determination of normal (average) year using the relative precipitation index RPI it was pos- 
Kasperek, R., Głowski, R. (2019). Hydroenergetic use of hydraulic structures on the Oława River. Acta Sci. Pol., Formatio Circumiectus, 18 (4), 177-186. DOI: http://dx.doi.org/10.15576/ASP.FC/2019.18.4.177

Table 2. Characteristic flows of the I-st degree, Oława river, Oława cross-section

\begin{tabular}{cccccccccccc}
\hline Flows & \multicolumn{10}{c}{ Research period } \\
\hline$\left[\mathrm{m}^{3} \cdot \mathrm{s}^{-1}\right]$ & 2005 & 2006 & 2007 & 2008 & 2009 & 2010 & 2011 & 2012 & 2013 & 2014 & 2015 \\
\hline $\mathrm{WQ}$ & 23.80 & 36.20 & 14.40 & 10.80 & 41.90 & 26.70 & 25.10 & 18.60 & 29.50 & 10.90 & 8.15 \\
\hline $\mathrm{SQ}$ & 3.03 & 4.53 & 3.85 & 3.38 & 4.89 & 6.89 & 4.78 & 3.35 & 4.88 & 3.09 & 2.50 \\
\hline $\mathrm{NQ}$ & 0.84 & 0.86 & 0.82 & 1.54 & 1.00 & 2.28 & 1.35 & 1.35 & 2.09 & 2.08 & 2.00 \\
\hline
\end{tabular}

Table 3. Characteristic flows of the II-nd degree, Oława river, Oława cross-section

\begin{tabular}{|c|c|c|c|c|c|}
\hline $\begin{array}{l}\text { Water } \\
\text { gauge }\end{array}$ & River & $\begin{array}{l}\text { Research } \\
\text { period }\end{array}$ & & $\begin{array}{c}\text { Flows } \\
\text { characteristic }\left[\mathrm{m}^{3} \cdot \mathrm{s}^{-1}\right]\end{array}$ & \\
\hline & & & $\begin{array}{c}\text { SWQ } \\
\text { (mean annual maximum } \\
\text { flows) }\end{array}$ & $\begin{array}{c}\text { SSQ } \\
\text { (mean annual average } \\
\text { flows) }\end{array}$ & $\begin{array}{c}\text { SNQ } \\
\text { (mean annual minimum } \\
\text { flows) }\end{array}$ \\
\hline \multirow[t]{5}{*}{ Oława } & Oława & $2005-2015$ & 22.37 & 4.11 & 1.47 \\
\hline & & & WWQ & WSQ & WNQ \\
\hline & & & 41.90 & 6.89 & 2.28 \\
\hline & & & NWQ & NSQ & NNQ \\
\hline & & & 8.15 & 2.50 & 0.820 \\
\hline
\end{tabular}

sible to calculate the river's hydropower potential at selected SHP locations. Precipitation conditions in the Oława catchment were assessed by calculating the ratio of precipitation sum in a selected period to an average long-term sum, functioning as the norm (Kaczorowska, 1962). Based on research and analysis, Kaczorowska defined the classification of humidity conditions, adopting the criteria: average year with the precipitation sum of $90-110 \%$ of normal precipitation, dry year with the sum of $75-89 \%$ and wet year with the sum of $111-125 \%$ of the normal year. Data from Wiązów precipitation station was used to calculate the average year. Based on the amount of annual precipitation sums from the period 2005-2015, the RPI indicator was determined from the formula $\mathrm{RPI}=\left(\mathrm{P}_{\mathrm{av}} / \sum \mathrm{P}\right)$ $\cdot 100 \%$, where $\mathrm{P}_{\mathrm{av}}$ is the average value of precipitation in the period $[\mathrm{mm}]$ and $\sum \mathrm{P}$ is precipitation sum in the examined period [mm]. The calculations show that, according to the adopted classification, there are several 'average' years in the period considered that could represent a normal year. The 2014 was chosen as the average year with precipitation sum close to the longterm average taken as the norm $(659 \mathrm{~mm})$.

\section{Hydrological constructions on the Otawa river}

The Oława river is developed with various types of hydrotechnical constructions. which mainly occur in the middle section of its course. The river has no active hydropower plants. The authors examined existing structures in terms of constructing SHPs, potential new locations and assessed their technical conditions and the possibilities of increasing their damming height. The research was carried out on the section of the river from Ziębice to Wrocław, through the municipalities of Henryków, Strzelin, Częszczyce, Wiązów, Kalinowa, Kurów, Siecieborowice, Drzemlikowice and Oława. The 14 stages of fall were located and their technical and hydraulic parameters were dimensioned (see: Table 4). In order to increase hydraulic slopes on damming buildings, the authors proposed a reconstruction of existing devices.

Preliminary calculations of the backwater range on individual hydraulic structures - understood in energetic terms - indicate that it has no effect on water levels in the lower positions and on the slope of structures located above. Preliminary analysis of 
water table system as a result of increased damming should not significantly change the water regime. The authors predict further detailed research and analysis to determine the water table system due to damming on water structures and impact on adjacent areas and backwater range of the river. The results of these analyses will be published in the next publications.

In the research area in the Oława river catchment there are no areas protected by state or commune law, and therefore there is no conflict with the objectives of protecting this type of area.

Table 4. Hydraulic structures on the Oława river

\begin{tabular}{|c|l|l|}
\hline No. & Location name and $\mathrm{km}$ & \multicolumn{1}{c|}{ Characteristics of the construction } \\
\hline 1 & Strzelin 61.5 & Double-gate valve weir, steel and reinforced concrete, damming height $\mathrm{H}=1.60 \mathrm{~m}$ \\
\hline 2 & Strzelin 60.8 & Double-gate valve weir, steel and reinforced concrete, damming height $\mathrm{H}=1.30 \mathrm{~m}$ \\
\hline 3 & Częszczyce 55.5 & Barrage with valves, concrete, $\mathrm{H}=1.00 \mathrm{~m}$ \\
\hline 4 & Wiązów 50.8 & Barrage with valves, concrete, $\mathrm{H}=1.00 \mathrm{~m}$ \\
\hline 5 & Wiązów 49.8 & Double-gate valve weir, steel and reinforced concrete, damming height $\mathrm{H}=2.66 \mathrm{~m}$ \\
\hline 6 & Kalinowa 48.4 & Barrage with valves, concrete, $\mathrm{H}=0.70 \mathrm{~m}$ \\
\hline 7 & Kalinowa 46.8 & Double-gate valve weir, steel and reinforced concrete, damming height $\mathrm{H}=1.28 \mathrm{~m}$ \\
\hline 8 & Kalinowa 47.9 & Barrage without valves, concrete, $\mathrm{H}=1.10 \mathrm{~m}$ \\
\hline 9 & Kurów 43.7 & Double-gate valve weir, steel and reinforced concrete, damming height $\mathrm{H}=1.40 \mathrm{~m}$ \\
\hline 10 & Siecieborowice 42.9 & Barrage with valves, concrete, $\mathrm{H}=0.80 \mathrm{~m}$ \\
\hline 11 & Drzemlikowice 42.4 & Barrage with valves, concrete, $\mathrm{H}=0.80 \mathrm{~m}$ \\
\hline 12 & Oława 24.2 & Barrage with valves, concrete, $\mathrm{H}=0.80 \mathrm{~m}$ \\
\hline 13 & Oława 21.4 & Barrage with valves, concrete, $\mathrm{H}=0.70 \mathrm{~m}$ \\
\hline 14 & Wroclaw 1.1 & Double-gate valve weir, steel and reinforced concrete, damming height $\mathrm{H}=1.30 \mathrm{~m}$ \\
\hline
\end{tabular}

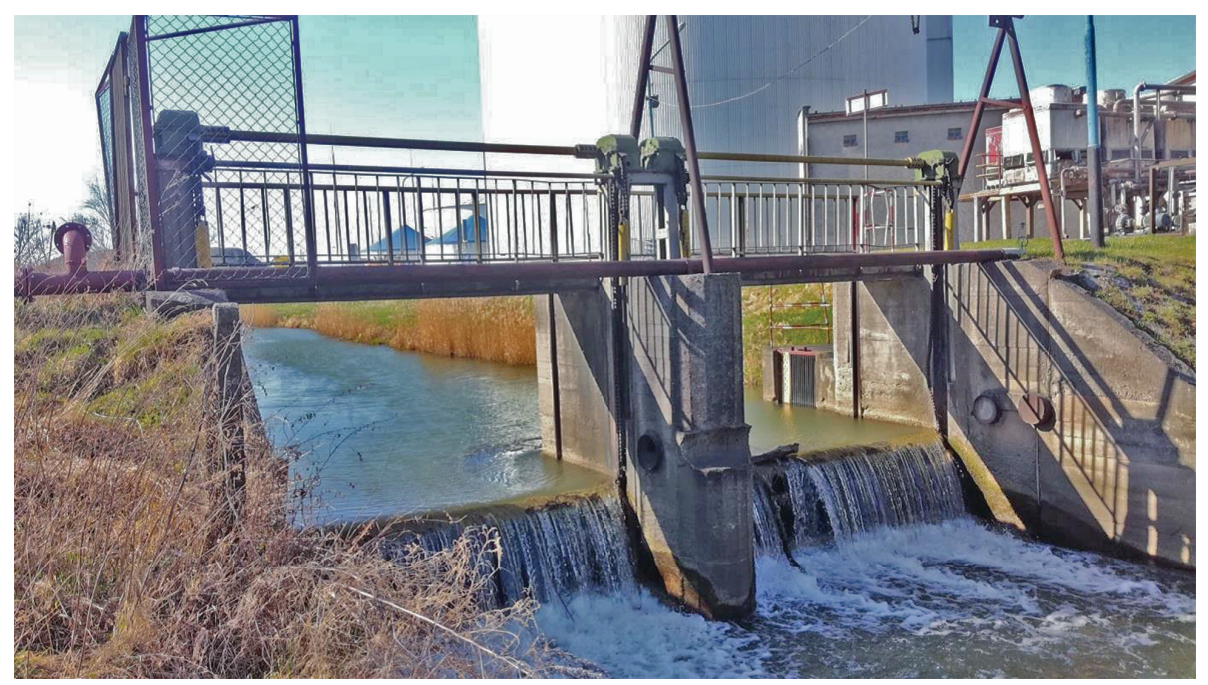

Fig. 2. An example of a hydraulic structure on the Oława river - Double-gate weir at $\mathrm{km} 61.514$ 


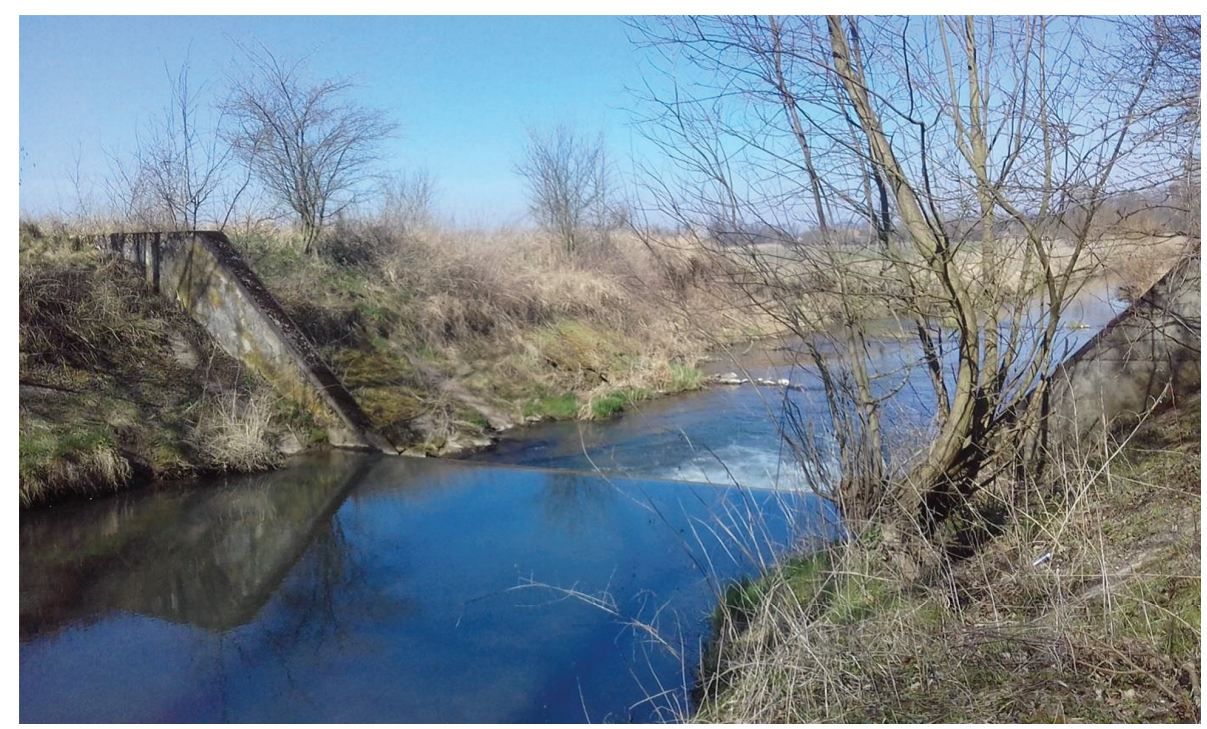

Fig. 3. An example of a hydraulic structure on the Oława river - concrete barrage at $\mathrm{km} 61.514$

\section{RESULTS AND DISCUSSION}

Both existing dammings and potential locations of SHP determined by field tests were situated on the river checked in uncontrolled cross-sections in accordance with hydrological conditions. The estimated characteristic flows from the Oława and the Zborowice water gauge stations were transferred by interpolation and extrapolation (Ozga-Zielińska, 1997) to the planned locations of the power plant according to the relationship $Q_{0}=Q_{i n}\left(A_{0} / A_{i n}\right)^{n}$, where $Q_{0}$ is a flow in the calculated/uncontrolled section, $Q_{\text {in }}$ the flow in the water gauge section, $A_{0}$ is the catchment area in the uncontrolled section, $A_{\text {in }}$ the catchment area in the water gauge section. The empirical parameter $\mathrm{n}$ is determined depending on the specific catchment, river section and specific characteristic flow. For medium and minimum flows, the value of $n=1$ was assumed for the Olawa river. Based on this equation, the catchment areas were determined for the proposed locations of SHP. The characteristic flows at the Olawa and Zborowice gauge stations were used to interpolate and calculate the SSQ flow in uncontrolled sections, where the locations of SHP are projected. Taking into account the modernization of hydrological structures, new dammings and slopes on the dammings have been adopted (see: Table 5).
Table 5. Catchment area, flows and slopes in the proposed SHP locations on the Oława river

\begin{tabular}{llccc}
\hline No. & \multicolumn{1}{c}{$\begin{array}{c}\text { Location } \\
\text { Km }\end{array}$} & $\begin{array}{c}\text { A } \\
\left(\mathrm{km}^{2}\right)\end{array}$ & $\begin{array}{c}\text { SSQ } \\
\text { avean annual } \\
\left(\mathrm{m}^{3} \cdot \mathrm{s}^{-1}\right)\end{array}$ & $\begin{array}{c}\mathrm{H} \\
(\mathrm{m})\end{array}$ \\
\hline 1 & Strzelin 61.5 & 260.70 & 0.96 & 2.00 \\
\hline 2 & Strzelin 60.8 & 262.86 & 0.97 & 2.00 \\
\hline 3 & Częszczyce 55.5 & 419.94 & 1.88 & 2.00 \\
\hline 4 & Wiązów 50.8 & 560.00 & 2.05 & 2.00 \\
\hline 5 & Wiązów 49.8 & 583.38 & 2.51 & 3.00 \\
\hline 6 & Kalinowa 48.4 & 586.00 & 2.52 & 2.00 \\
\hline 7 & Kalinowa 46.8 & 589.31 & 2.53 & 2.00 \\
\hline 8 & Kalinowa 47.9 & 595.00 & 2.53 & 2.00 \\
\hline 9 & Kurów 43.7 & 603.05 & 2.56 & 2.00 \\
\hline 10 & Siecieborowice 42.9 & 610.15 & 2.60 & 1.80 \\
\hline 11 & Drzemlikowice 42.4 & 610.91 & 2.62 & 1.80 \\
\hline 12 & Oława 24.2 & 960.40 & 4.12 & 1.20 \\
\hline 13 & Oława 21.4 & 980.20 & 4.51 & 1.50 \\
\hline 14 & Wroclaw 1.1 & 1120.00 & 6.22 & 2.00 \\
\hline & & & & \\
\hline
\end{tabular}




\section{Calculations of spillway capacity, power and energy production}

In order to determine the hydropower potential of the Oława river, the spillway capacity and potential power of SHP as well as the production of annual energy were estimated. For this reason, the Hoffmann method was employed (Hoffman, 1991; Kasperek and Wiatkowski, 2014). According to its assumptions, power $P$ was calculated from model $P=8.2 \times Q_{i} \cdot \mathrm{H}[\mathrm{kW}]$, where: 8.2 means the product of water weight and the average efficiency of power plant equipment $\left[\mathrm{kN} \cdot \mathrm{m}^{-3}\right], Q_{i}$ water flow (spillway capacity) $\left[\mathrm{m}^{3} \cdot \mathrm{s}^{-1}\right]$, H slope $[\mathrm{m}]$.

The spillway capacity $Q_{i}$ was estimated based on the average annual flow of SSQ in the damming cross-section. The possible spillawy capacity $Q_{i}$ were analysed for three variants to which the specified capacity utilisation time $T_{E}$ was estimated, i.e.:

- variant I: $Q_{i}=(0.8-0.95) \cdot \mathrm{SSQ}, T_{E}=6000 \mathrm{~h}$,

- variant II: $Q_{i}=\mathrm{SSQ}, T_{E}=5500 \mathrm{~h}$,

- variant III $Q_{i}=(1.1-1.3) \cdot \mathrm{SSQ}, T_{E}=5000 \mathrm{~h}$.

Finally, the authors adopted for calculations the variant I, which assumed the capacity of $Q_{i}=0.9 \cdot \mathrm{SSQ}$, power utilisation time $T_{E}=6000$ hours and energy production is determined from formula $E_{E}=T_{E} \cdot P$ (see: Table 6).

Table 6. Power P and annual energy production E for proposed SHP locations on the Oława river

\begin{tabular}{clcccc}
\hline No. & \multicolumn{1}{c}{$\begin{array}{c}\text { Location } \\
\mathrm{Km}\end{array}$} & $\begin{array}{c}H \\
(\mathrm{~m})\end{array}$ & $\begin{array}{c}Q_{i} \\
\left(\mathrm{~m}^{3} \cdot \mathrm{s}^{-1}\right)\end{array}$ & $\begin{array}{c}P \\
(\mathrm{~kW})\end{array}$ & $\begin{array}{c}E \\
(\mathrm{MWh})\end{array}$ \\
\hline 1 & Strzelin 61.5 & 2.0 & 0.86 & 14.2 & 85.0 \\
\hline 2 & Strzelin 60.8 & 2.0 & 0.87 & 14.3 & 85.9 \\
\hline 3 & Częszczyce 55.5 & 2.0 & 1.69 & 27.7 & 166.5 \\
\hline 4 & Wiązów 50.8 & 2.0 & 1.85 & 30.3 & 181.5 \\
\hline 5 & Wiązów 49.8 & 3.0 & 2.26 & 55.6 & 333.4 \\
\hline 6 & Kalinowa 48.4 & 2.0 & 2.27 & 37.2 & 223.2 \\
\hline 7 & Kalinowa 46.8 & 2.0 & 2.28 & 37.3 & 224.1 \\
\hline 8 & Kalinowa 47.9 & 2.0 & 2.28 & 37.3 & 224.1 \\
\hline 9 & Kurów 43.7 & 2.0 & 2.30 & 37.8 & 226.7 \\
\hline 10 & Siecieborowice 42.9 & 1.8 & 2.34 & 34.5 & 207.2 \\
\hline 11 & Drzemlikowice 42.4 & 1.8 & 2.36 & 34.8 & 208.8 \\
\hline 12 & Oława 24.2 & 1.2 & 3.71 & 36.5 & 218.9 \\
\hline 13 & Oława 21.4 & 1.5 & 4.06 & 49.9 & 299.6 \\
\hline 14 & Wroclaw 1.1 & 2.0 & 5.60 & 91.8 & 550.8 \\
\hline
\end{tabular}

The results of the calculations show that the hydropower potential of the Olawa river for 14 potential SHPs is estimated at $3.24 \mathrm{GWh}$ for the average year. This is the potential adjusted by the average annual capacity utilisation rate of 6,000 hours. Assuming electricity consumption over a year by a family of 4 in a household of 2,613 MWh, the energy needs of about 1,240 households could be met.

The calculations above illustrate the possible method of managing energy from the dammings on the Oława river, which are not currently utilised. For environmental and social reasons, the construction of SHP as alternative and renewable energy sources is most desirable. Given Poland's commitments to the EU regarding renewable energy, small hydropower plants do not show disadvantages typical of such investments. In practice, there is no or minimised need to resettle residents from adjacent areas, which usually leads to community's protests. Small hydropower plants are also much cheaper to build than large ones, thus providing great space for development in our country while resolving the obligations under EU directives (Dyrektywa PE 2018, Ustawa 2019).

The cost-effectiveness of the construction of SHPs is much lower than large power plants, as the refunds are greater than the investment. The amount of unit expenditure per $1 \mathrm{kWh}$ of annual production and a unit cost of $1 \mathrm{~kW}$ of installed capacity are important for the results of the economic analysis of hydropower plants. Using literature data e.g. from the international HIDROENERGIA conferences and the results of the economic analyses of the 38 SHPs contained in the Introduction of this paper, it should be noted that there are strict relationships between power and slope and unit investment expenditure per $1 \mathrm{~kW}$ of power installed. According to the authors' own calculations, the costs of constructing a SHP on the Olawa will range between PLN 300000 for power plants with an installed power capacity of $14 \mathrm{~kW}$ and PLN 1935000 for a power capacity of $90 \mathrm{~kW}$. Initially, it is estimated that the reimbursement period for the construction of SHP will take around 10 years. A detailed economic analysis of the construction of potential SHP on the Olawa river will be presented by the authors in subsequent publications.

It is worth noting that this research paper analysed hydroenergy potential on the basis of 14 major and existing hydrotechnical facilities of the Oława river, but these are not all structures found on the wa- 
tercourse. Also, there are locations where new dammings can be built.

The authors proposed for the potential SHP locations, which are characterized by a slope in the range of 1 to $3 \mathrm{~m}$, a construction of a hydroelectric power plant with Archimedes' screw. The use of low-slope technologies is the most economically efficient for analysed locations and also allows for less environmental interference, as these turbines are known for their environmental friendliness for fluvial wildlife. Due to its simplicity and durability, relatively low investment and operating costs, as well as the possibility of installing variable flows and low slope in locations, Archimedes' screw has gained popularity as alternative to the use of traditional water turbines. This is evidenced primarily by the numerous investments made using it worldwide, as well as in our country, especially in Natura 2000 areas. It is currently used in upgraded or newly built SHPs, which is also part of the proposed SHP locations on the Oława river.

\section{CONCLUSIONS}

The Oława, like most rivers in Poland, runs through lowlands with a relatively small slope. The research showed that despite inconvenient hydropower conditions, it is worth considering utilising the potential of this river. It included an analysis of 14 hydrotechnical objects located on the watercourse. Developing each of the damming structures gives an opportunity for a source of clean and renewable energy. As a result of the study, the river's hydropower potential was estimated at $3.24 \mathrm{GWh}$, which currently is not used at all. Thus, these scarce water resources are irretrievably lost, despite the fact that investing in SHP significantly contributes to the local energy network. The potential of the Oława river could provide clean electricity for 1240 farms. Utilising Oława's hydropower potential would reduce emissions to the atmosphere, stabilizing surrounding hydrological conditions and guaranteeing better living for people.

It should be borne in mind that this year the European Parliament has started serious discussions on setting new targets for member states for 2030 regarding the amount of energy obtained from renewable energy, even up to $30 \%$. The main reason in their favour of renewable energy sources are reduced costs. This means that individual countries could increase their goals at a much lower cost than assumed in 2014.

\section{REFERENCES}

Depczyński, W., Szamowski, A. (1999). Budowle i zbiorniki wodne. Warszawa: Oficyna Wydawnicza Politechniki Warszawskiej.

Dolata, B. (2012). Polski rynek energetyki wodnej na tle hydroenergetyki krajów Unii Europejskiej. Energetyka Wodna, 1, 31-33.

Dyrektywa Parlamentu Europejskiego i Rady(UE) 2018/2001 z dnia 11 grudnia 2018 r. w sprawie promowania stosowania energii ze źródeł odnawialnych. Dz.U. UE L 328/82.

Fu, G., Ni, G., Zhang, C. (2019). Recent advances in adaptive catchment management and reservoir operation. Water (Switzerland), 11, 1-7. DOI:10.3390/w11030427.

Gąsiorek, J., Kasperek, R., Sołtys, J., Wiatkowski, M. (2006). Hydroenergetyczny potencjał rzeki Kwisy. Część II. Ocena bilansu energetycznego rzeki Kwisy. Polskie Towarzystwo Przyjaciół Nauk o Ziemi, 13, 207-215.

Hauer, C., Wagner, B., Aigner, J., Holzapfel, P., Flödl, P., Liedermann, M., Tritthart, M., Sindelar, C., Pulg, U., Klösch, M., Haimann, M., Donnum, B.O., Stickler, M., Habersack, H. (2018). State of the art, shortcomings and future challenges for a sustainable sediment management in hydropower: A review. Renewable and Sustainable Energy Reviews, 98, 40-55. DOI:10.1016/j.rser.2018.08.031.

Henke, A., Kaniecki, M., Steller, J. (2010). Jak wybudować małą elektrownię wodną? Przewodnik inwestora. Cz. 1 i 2. ESHA, Bruksela/Warszawa.

Hoffman, M. (1991). Małe elektrownie wodne - poradnik. Warszawa: Nabba Sp. z o.o.

Isaac, N., Eldho, T.I. (2019). Sediment removal from run-of -the-river hydropower reservoirs by hydraulic flushing. International Journal of River Basin Management, 17, 389-402. DOI:10.1080/15715124.2019.1583667.

Kaczorowska, Z. (1962). Opady w Polsce w przekroju wieloletnim. Warszawa: Wydawnictwo Geologiczne.

Kalina, Ł. (2019). Przepławka aktywna ekonomicznym sposobem na udrożnienie biologiczne rzek. Energetyka Wodna, 3, 48-49.

Kasperek, R., Wiatkowski, M. (2008). Terenowe badania funkcjonowania przepławki dla ryb na zbiorniku Michalice. Rocznik Ochrona Środowiska, 10, 613-622.

Kasperek, R., Wiatkowski, M. (2010). Analiza możliwości budowy małych elektrowni wodnych na rzece Nysie Kłodzkiej. Praca zbiorowa pod redakcją Cz. Rosik-Dulewska, M. Wiatkowski, Uniwersytet Opolski, 53-65.

Kasperek, R., Wiatkowski, M. (2014). Hydropower generation on the River Nysa Kłodzka. Ecological Chemistry and Engineering, 21(2), 327-336, DOI: 10.2478/eces2014-0025. 
Miazga, L. (2013). Ogólnopolski program budowy małych elektrowni wodnych - korzyści, zagrożenie, konieczność. Energetyka Wodna, 3, 16-20.

Michalec, B., Cupak, A., Tarnawski, M., Wałega, A. (2017). Assessment of the technical state of the weir at Szczyglice on the Rudawa River. Acta Sci. Pol. Form. Cir., 16(4), 5-12, DOI: 10.15576/ASP.FC/2017.16.4.5.

Operacz, A., Grahl-Madsen, M. (2018). Program of hydropower potential assessment as an effective possibilities in Upper Vistula water region in Poland. Acta Sci. Pol. Form. Cir., 17(4), 157-172, DOI: 10.15576/ASP. FC/2018.17.4.157.

Ossberger GmbH. (2019). Ożywienie potencjału energii wodnej podnosi walory ekologiczne. Energetyka Wodna, 32-33.

Ozga-Zielińska, M. (1997). Hydrologia stosowana. Warszawa: PWN.

Pęcherz, E., Szlęzak, R. (2017). Śruby Archimedesa - doświadczenie eksploatacyjne i nowe możliwości zastosowań. Energetyka Wodna 4, 14-15.

Rozporządzenie Ministra Środowiska z dnia 20 kwietnia 2007 r. w sprawie warunków technicznych, jakim powinny odpowiadać budowle hydrotechniczne i ich usytuowanie. Dz.U. 2007 nr 86 poz. 579.

Sindelar, C., Schobesberger, J., Habersack, H. (2017). Effects of weir height and reservoir widening on sediment continuity at run-of-river hydropower plants in gravel bed rivers. Geomorphology, 291, 106-115.

Steller, J. (2013). Badania małych turbin niskospadowych - metodyka i doświadczenia praktyczne z polskich elektrowni wodnych. Energetyka Wodna, 3, 36-42.

Szkudlarek, A., Mokwa, M., Kasperek, R. (2019). High gradient meander - modular fish passes for hydroelektric power objects, Acta Sci. Pol. Form. Cir., 18(4), $125-136$.

Ustawa z dnia 19 lipca 2019 r. o zmianie ustawy o odnawialnych źródłach energii oraz niektórych innych ustaw, Dz.U. 2019 poz. 1524.

Wagner, B., Hauer, C., Schoder, A., Habersack, H. (2019). A review of hydropower in Austria: Past, present and future development. Renewable and Sustainable Energy Reviews, 50, 304-314.

Wiatkowski, M., Kasperek, R. (2012). Initial assessment of the power generation potential of selected hydropower plants in the dolnoslaskie and opolskie provinces. Proccedings of ECOpole, 6(2), 553-558, DOI: 10.2429/ proc.2012.6(2)075.

Wiatkowski, M., Rosik-Dulewska, C. (2012). Stan obecny i możliwości rozwoju energetyki wodnej w województwie Opolskim. Woda-Środowisko-Obszary Wiejskie, 2(38), 313-327.

\section{HYDROENERGETYCZNE WYKORZYSTANIE BUDOWLI WODNYCH NA RZECE OŁAWA}

\section{ABSTRAKT}

\section{Cel pracy}

Celem pracy jest inwentaryzacja budowli wodnych na rzece Oława pod kątem budowy elektrowni wodnych oraz ocena jej potencjału hydroenergetycznego.

\section{Materiały i metody}

Na rzece Oława nie ma żadnej małej elektrowni wodnej. Autorzy przeprowadzili pomiary i obliczenia przepływów i stanów wody dla okresu 2005-2015, klasyfikację warunków wilgotnościowych i przyjęcia roku przeciętnego będącego podstawą do obliczeń hydroenergetycznych, inwentaryzację budowli wodnych oraz obliczenia potencjału rzeki. Wyznaczono rok przeciętny za pomocą wskaźnika RPI. Autorzy wykonali inwentaryzację istniejących budowli w terenie pod kątem budowy MEW oraz ocenili ich stan techniczny i możliwości zwiększenia spadów. Oszacowano przełyki, potencjalną moc proponowanych lokalizacji MEW oraz produkcję rocznej energii w oparciu o metodę Hoffmanna. Moc określono ze wzoru $\mathrm{P}=8,2 \mathrm{QH}$, gdzie przełyk Q przyjęto na poziomie 0,9SSQ, spady H przyjęto w oparciu o badania budowli, a produkcję energii wyznaczono z formuły $\mathrm{E}=\mathrm{TP}$, gdzie czas wykorzystania mocy $\mathrm{T}=6000 \mathrm{~h} / \mathrm{rok}$.

\section{Wyniki i wnioski}

Analizie poddano 14 obiektów zlokalizowanych na rzece Oława. Oszacowano jej potencjał hydroenergetyczny na poziomie 3,24 GWh. Jest on w stanie zapewnić czystą energię elektryczną dla 1240 gospodarstw. Takie wykorzystanie potencjału Oławy przyczyniłoby się do zmniejszenia emisji zanieczyszczeń, stabilizację warunków hydrologicznych w rzece oraz zagwarantowałoby lepsze warunki życia ludzi.

Słowa kluczowe: rzeka, jaz, elektrownia wodna, turbina Archimedesa, produkcja energii 